\begin{tabular}{|l|l|l|l|l|}
\hline ACTA CARSOLOGICA & $32 / 2$ & 5 & $53-64$ & LJUBLJANA 2003 \\
\hline
\end{tabular}

COBISS: 1.01

\title{
THE USE OF STRUCTURAL GEOLOGICAL TERMS AND THEIR IMPORTANCE FOR KARST CAVES
}

\section{UPORABA STRUKTURNO GEOLOŠKIH IZRAZOV IN NJIHOV POMEN ZA KRAŠKE JAME}

STANKA ŠEBELA ${ }^{1}$

${ }^{1}$ Karst Research Institute ZRC SAZU, Titov trg 2, SI-6230 Postojna, Slovenia, sebela@zrc-sazu.si

Prejeto / received: 25. 8. 2003 


\section{Stanka Šebela: The use of structural geological terms and their importance for karst caves}

Structural geological studies on karst areas operate with the same structural geological terms as on other geological regions. But because of special geomorphologic terms characterized for karst areas, some structural geological elements, which are in a special way connected with particular karst forms, are used as a special terms, different from those used on non-karstic areas. For Slovene karst we need to divide two most important structural elements that are important for development of cave passages, bedding planes and tectonic structures. And between bedding planes the ones that are tectonically disrupted are very favorable for development of initial cave passages. In the longest Slovene karst caves as Postojnska jama caves, Predjama and Škocjanske jame caves interbedded movements, thrusting and folding deformations, and tectonically broken zones (fissured, broken and crushed zones) are very favorable for initial, and also for older and younger stages of passage development.

Key words: structural geological terms, karst caves, Slovenia.

Izvleček

UDK: 551.44:001.4

\section{Stanka Šebela: Uporaba strukturno geoloških izrazov in njihov pomen za kraške jame}

Strukturno geološke raziskave na kraških terenih zajemajo enake strukturno geološke izraze kot na drugih geoloških terenih. Ker pa imamo na krasu opravka s posebnimi geomorfološkimi izrazi, se nekateri strukturno geološki elementi, ki so na poseben način povezani z določenimi kraškimi oblikami, uporabljajo kot posebni termini, ki so različni od terminov v uporabi na nekraških terenih. Na slovenskem krasu lahko ločimo dva najpomembnejša strukturna elementa, ki sta pomembna za razvoj jamskih rovov, in sicer lezike in tektonske strukture. Med lezikami so za razvoj inicialnih rovov posebno ugodne tektonsko deformirane lezike. V najdaljših slovenskih jamah, kot so Postojnska, Predjama in Škocjanske jame so za razvoj rovov v inicialnih, kot tudi v starejših in mlajših obdobjih zelo ugodni medplastni zmiki, deformacije narivanja in gubanja ter tektonsko pretrte cone (razpoklinske, porušene in zdrobljene).

Ključne besede: strukturno geološki izrazi, kraške jame, Slovenija. 


\section{INTRODUCTION}

Geological structure is one of the keys for understanding the development and formation of karst areas. Structural geological studies on karst areas operate with the same structural geological terms as on other geological regions. But because of special geomorphological terms characterised for karst areas, some structural geological elements, which are in a special way connected with particular karst forms, are used as a special terms, different from those used on non-karstic areas. We need to divide:

- $\quad$ bedding planes (tectonically disrupted)

- tectonic structures (faults, thrusting and folding deformations, tectonically broken zones).

\section{TECTONICALLY DISRUPTED BEDDING PLANES}

On numerous limestone beds in Postojnska jama cave system it was possible to determine tectonic striae which give an indication of interbedded movements (Table 1) which occurred during the formation of the Postojna anticline (Gospodarič 1965 and 1976). Some bedding planes have double striation, what shows there have been two tectonic processes: the older one having folded the strata, and younger faulting where horizontal movements of the blocks were formed (Gospodarič 1964).

Car \& Gospodarič (1984) mentioned Lower Cretaceous limestone beds with striation on the bedplanes.

The importance of bedding planes emphasised by interbedded movements was determined in Postojnska jama cave system (Šebela 1998). In the same study (Šebela 1998) we used the terms: interbedded movements deformed bedding, bedding planes broken by interbedded movements and slipped bedding planes. The expression moved bedding planes was used in 1998 by Čar \& Šebela.

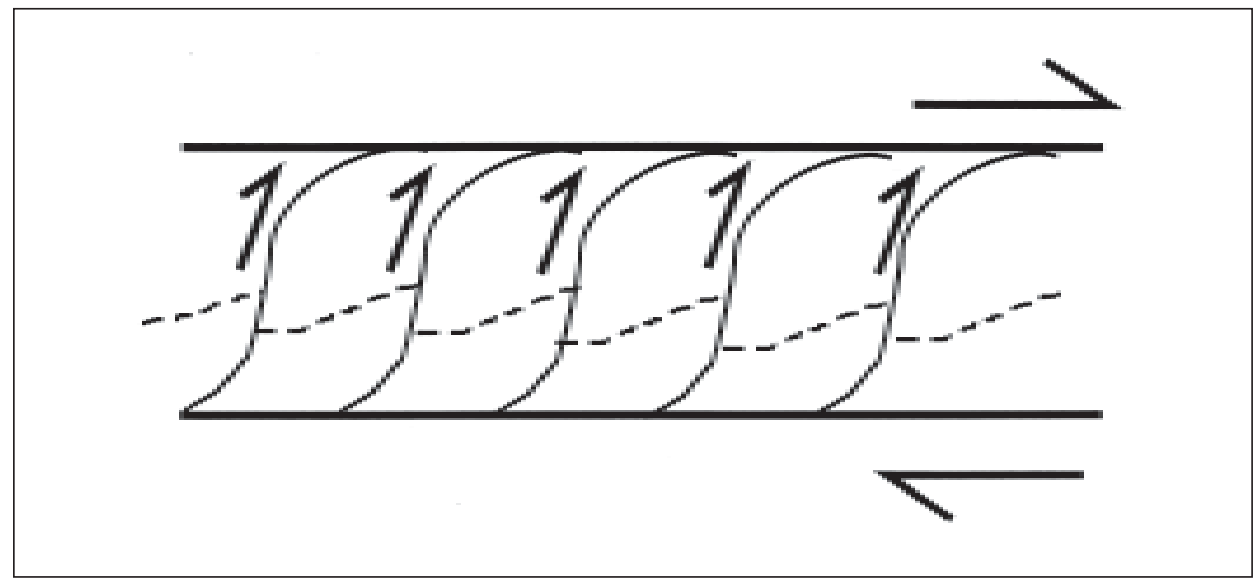

Fig. 1: Cross-section showing imbricate structure between roof and floor thrusts. The dotted line shows the displacement of one horizon (from Farris Lapidus 1990).

Slika 1: Prečni profil prekritih struktur med zgornjim in spodnjim narivom. Črtkane linije kažejo premike enega horizonta (iz Farris Lapidus 1990). 
Table 1: Terms used for tectonically disrupted bedding planes.

Tabela 1: Uporaba izrazov za tektonsko deformirane lezike.

\begin{tabular}{|c|c|c|c|}
\hline THE AUTHOR & YEAR & TERM IN ENGLISH & TERM IN SLOVENE \\
\hline Gospodarič & 1964 & bedding planes have double & lezike imajo \\
\hline 1965 anc & d 1976 & interbedded movements & medplastni zdrsi \\
\hline Davies & 1960 & bedding plane openings & odprtine ob lezikah \\
\hline Ford \& Ewers & 1978 & differential slipping & diferencialni zdrs \\
\hline Placer & 1982 & interbedded movements & medplastni premiki \\
\hline Čar \& Gospodarič & 1984 & $\begin{array}{l}\text { limestone beds with striation } \\
\text { on the bedplanes }\end{array}$ & $\begin{array}{l}\text { skladi apnenca } \\
\text { z drsinami ob lezikah }\end{array}$ \\
\hline Čar \& Šebela & 1998 & moved bedding planes & zdrsne lezike \\
\hline Šebela & 1998 & $\begin{array}{l}\text { bedding planes emphasised } \\
\text { by interbedded movements } \\
\text { interbedded movements } \\
\text { deformed bedding } \\
\text { bedding planes broken by } \\
\text { interbedded movements } \\
\text { slipped bedding planes }\end{array}$ & $\begin{array}{l}\text { lezike poudarjene z } \\
\text { medplastnimi zdrsi } \\
\text { medplastni zdrsi so } \\
\text { deformirali plastnatost } \\
\text { lezike deformirane z } \\
\text { medplastnimi zdrsi } \\
\text { zdrsne lezike }\end{array}$ \\
\hline Knez & 1998 & $\begin{array}{l}\text { interbedded slides } \\
\text { formative bedding-plane }\end{array}$ & $\begin{array}{l}\text { medplastni zdrsi } \\
\text { nosilna lezika }\end{array}$ \\
\hline Fowler \& Winsor & 1997 & $\begin{array}{l}\text { bedding slip plane } \\
\text { interlayer slip }\end{array}$ & $\begin{array}{l}\text { oblezična zdrsna ploskev } \\
\text { medplastni zdrs }\end{array}$ \\
\hline Cooke \& Pollard & 1997 & $\begin{array}{l}\text { frictional slip along } \\
\text { bedding planes }\end{array}$ & $\begin{array}{l}\text { frikcijski zdrs vzdolž } \\
\text { lezik }\end{array}$ \\
\hline Nińo et al. & 199 & Bed-parallel slip & zdrs vzporeden lezikam \\
\hline oehn \& Passchier & 2000 & bedding-parallel slip & zdrs vzporeden lezikam \\
\hline
\end{tabular}

In 1998 Knez stated that cave passages or their fragments and other traces of the underground karstification do not appear scattered at random on the walls of the Velika dolina in Škocjanske jame caves but are obviously gathered along small number of so called formative bedding-planes. A formative bedding-plane is defined as the bedding-plane where the early stage of speleogenesis started, generally up to the point of breakthrough from laminar to turbulent flow. At such beddingplanes the primary cave channels formed. Formative bedding-planes differ from others because the rock along these bedding-planes is typically damaged, indicating an interbedded slipping.

In any bedded limestone formation there are a great many bedding planes but only a small proportion are utilized during cave formation. Very often these display some clear feature that explains their preferential selection, such as a shale parting, a discontinuous chert filling, or slickensiding and minor brecciation indicative of differential slipping (Ford \& Ewers 1978, Renault 1967, Waltham 1971).

Within stress zone fractures and bedding plane openings afford routes along which solution occurs (Davies 1960). 


\section{TECTONIC STRUCTURES}

Between tectonic structures important for the formation of cave passages we need to divide:

- thrusting (duplex, thrust faults)

- folding (folds)

- faulting (tectonically broken zones, reverse and normal faults, strike-slip faults).

Duplex (Figure 1) is a series of imbricate thrust wedges bounded by a lower floor or sole thrust and an upper roof thrust. The individual imbricate units, which are lens-like in form and bounded on all sides by faults, are called horses (Farris Lapidus 1990).

Imbricate structure or imbrication is a tectonic structure in which a series of lesser thrust faults that overlap, and are nearly parallel, are all oriented in the same direction, which is towards the source of stress (Farris Lapidus 1990).

Duplex is a stack of thrust-bounded rock slices, bounded by a roof thrust and a floor thrust, formed through continued thrusting along the floor thrust with successive collapse of thrust ramps (www.schottishgeology.com/glossary.html).

In Stara Jama (Postojnska jama cave) the bedding is strongly tectonically deformed (Figure 2). In some places bedding planes are opened, inside them we can observe a $0,5 \mathrm{~cm}$ thick layer of secondary sparitic calcite veins. At the time of folding some bedding planes were deformed with interbedded movements. Interbedded movements can cross from one bedding plane to another. All bedding planes are not tectonically deformed, but in Stara Jama such bedding planes prevail (Čar \& Šebela 1998). In fact we have the example of a small scale duplex.

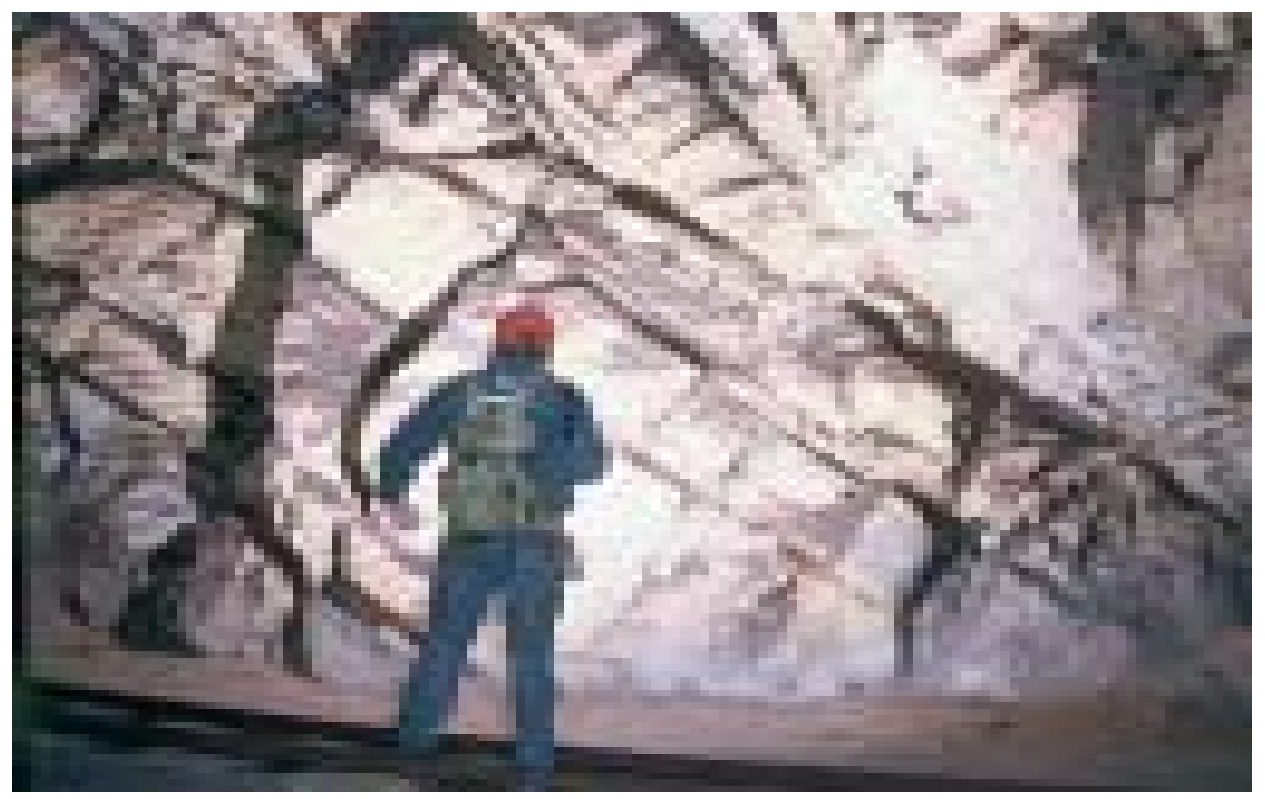

Fig.2: Duplex in Stara jama, Postojnska jama cave (photo by. S. Šebela).

Slika 2: Duplex v Stari jami, Postojnska jama (foto S. Šebela). 
In structural geological literature we find many examples of duplex forms. The »la Cagaličre« duplex (Averbuch et al. 1992, Laumonier et al. 1995, Frizon de Lamotte et al. 1997) is a well exposed hectometric scale structure situated at the front of the Lagrase fold (NE Pyrenees, France). It is made up of 4 sheets of Eocene limestone (Figure 3) sandwiched between a floor thrust which is the upper flat of the Lagrasse ramp related fold and a roof thrust flooring its allochtonous forelimb. The »la Cagaliere« duplex has been built between the folding and the out of sequence thrusting perhaps during the change in the tectonic transport direction (Frizon de Lamotte et al. 1997). Even if the »la Cagaliere« duplex is a big scale duplex the mechanism of the formation could be compared with small scale duplex in Stara jama.

The best example of folding deformations in Postojnska jama caves is so-called Postojna anticline (Gospodarič 1976, Šebela 1998).

Detailed structural-lithological mapping of karst surface (Čar 1982, Čar \& Gospodarič 1984 and 1988) and karst underground (Gospodarič 1976, Šebela \& Čar 1991, Šebela 1998) opened the discoussion about the need for new structural geological terms for karst. Gospodarič (1976) mostly used widely prevalent structural geological terms and used them for karst areas. Čar (1982) was the first one to determine new division for tectonically broken zones on karst. Maja Kranjc from Karst Research Institute ZRC SAZU (Postojna, Slovenia) translated them into English. In his papers Placer $(1981,1982)$ described the characterictics of exterior and inner fault zone (Table 2). He mentioned fissured zone, but did not introduce it into karst.

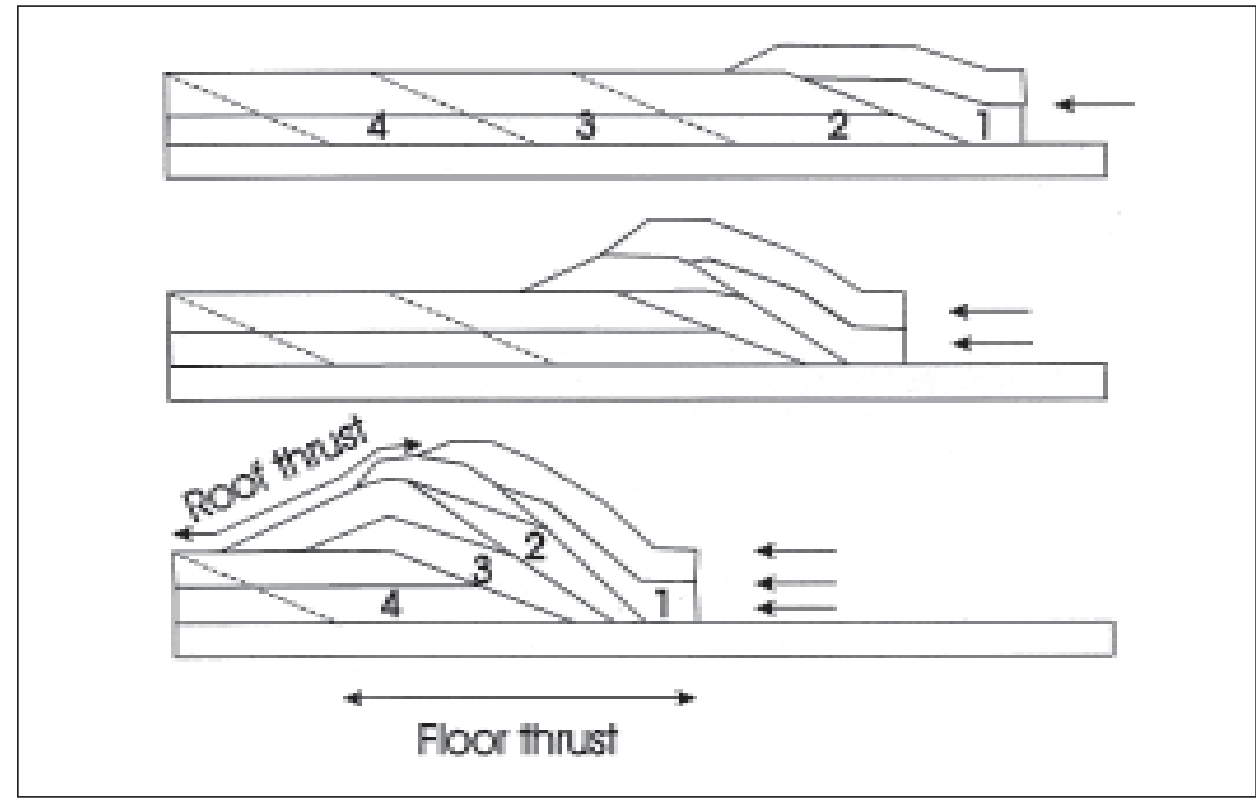

Fig. 3: La Cagaliere duplex, NE Pyrenees, France

(http://www.u-cergy.fr/rech/labo/equipes/tecto/Equipe/Christine_page_web/tt99.htm).

Slika 3: La Cagaliere duplex, SV Pireneji, Francija

(http://www.u-cergy.fr/rech/labo/equipes/tecto/Equipe/Christine_page_web/tt99.htm). 
Table 2 Terms used for tectonically broken zones in carbonate rocks.

Tabela 2 Uporaba izrazov za tektonsko pretrte cone v karbonatnih kamninah.

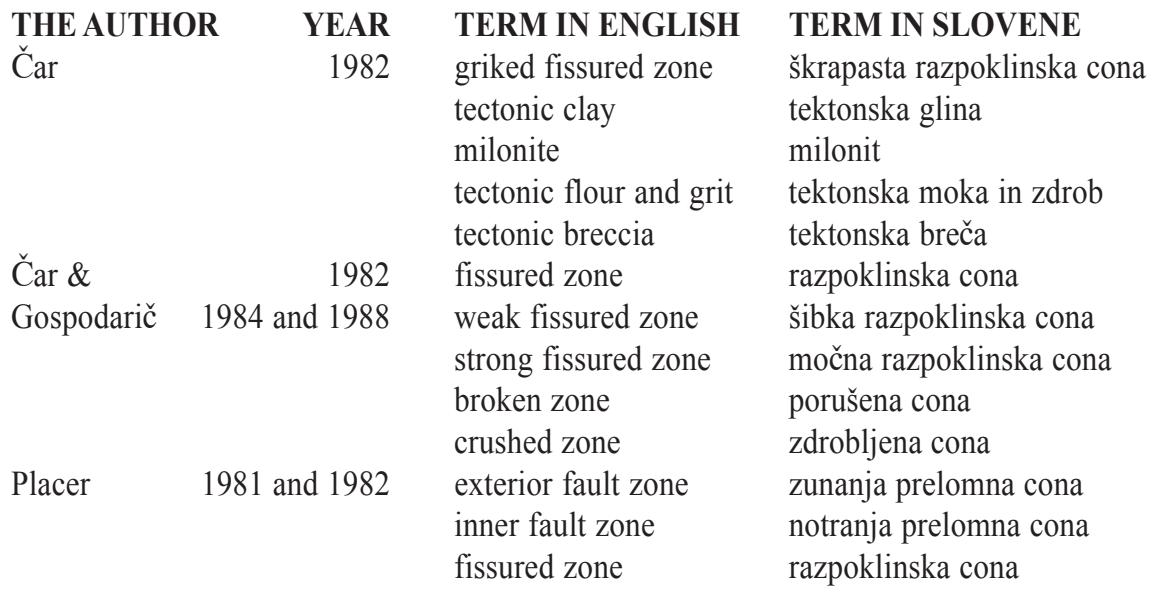

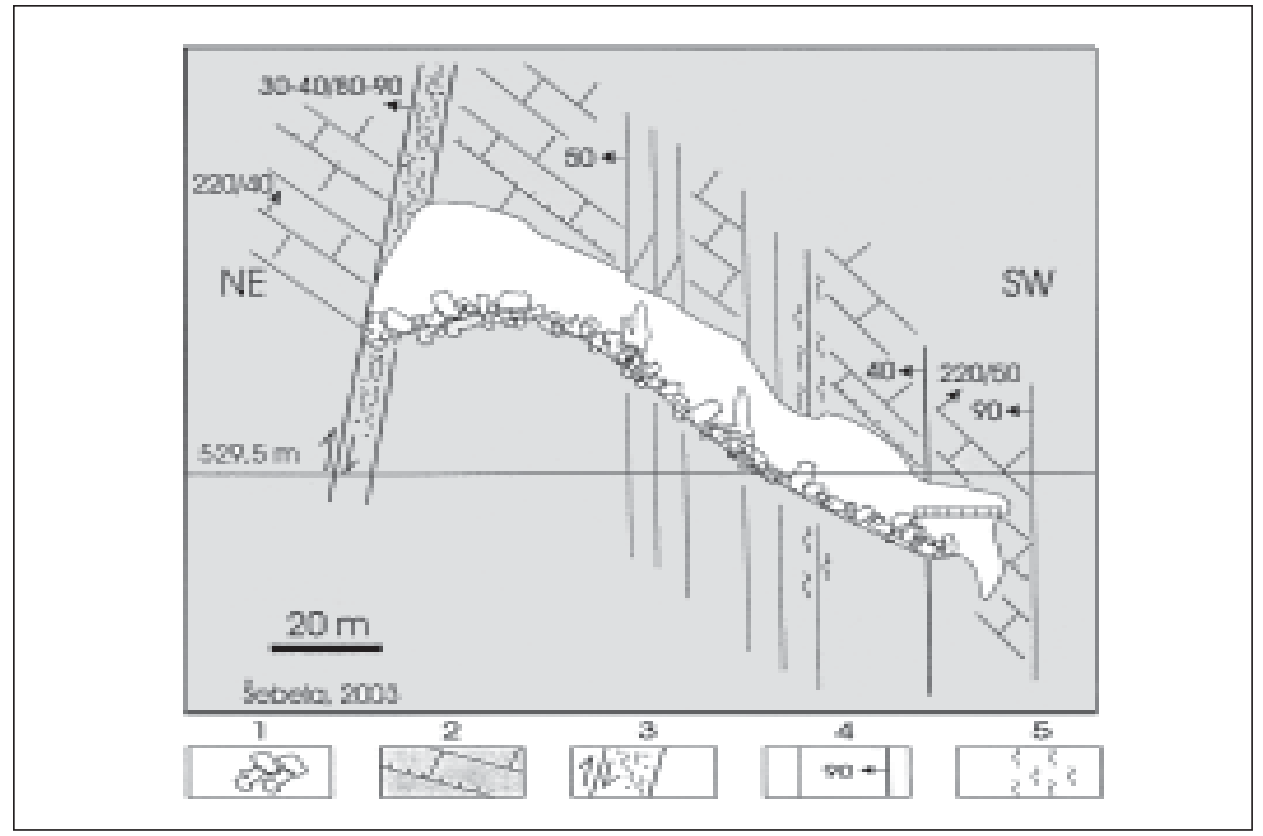

Fig. 4: Geological cross-section of Velika gora collapse chamber. 1-collapse blocks, 2-Upper Cretaceous limestone with interbedded slips, 3-fault zone with vertical movement, 4-weak and strong fault with strike direction, 5-fissured zone.

Slika 4: Geološki profil podorne dvorane Velika gora. 1-podorni bloki, 2-Zg. kredni apnenci z medplastnimi zdrsi, 3-prelomna cona z vertikalnim premikom, 4-šibka in močna prelomna cona s smerjo vpada, 5-razpoklinska cona. 
Gospodarič (1976) was the first who performed detailed geological mapping of karst surface and underground in Slovenia.

In the 1970s and early 1980s detailed structural geological mapping (1:5.000) of Planina polje ponor area was performed by C̆ar (1982). Tectonic conditions were studied in detail and described on the base of the tectonical map. The structures were defined on the base of deformed rock and space orientation (Čar \& Gospodarič 1984).

Regarding the tectonic fracturing of carbonate rocks we can distinguish three zone species: Fractured zone is practically impermeable, caracterized by tectonic clay, tectonic breccia and milonite "flour" and "grit". Partly and well permeable are collapsed zones, while fissured zones present an excellent permeable region thus in limestones as dolomites (Čar 1982).

Tectonically fractured zones have been divided by Čar (1982) into three subdivisions:

- fissured zone (least fractured, stratification still visible)

- broken (more fractured, rock often occurs as blocks, may be physically displaced, stratification not visible

- crushed zone (most fractured, stratification has been destroyed, tectonic breccia often present).

Translation by Aldwel in Knez et al. 1995.

The formation of Velika gora collapse chamber in Postojnska jama cave (Šebela 1995) is connected with the possition and reactivation of a reverse fault situated on the NE edge of the collapse chamber. The fault was probably reactivated during the speleological history of the cave and thus the formation of the collapse chamber depends on the fault activity.

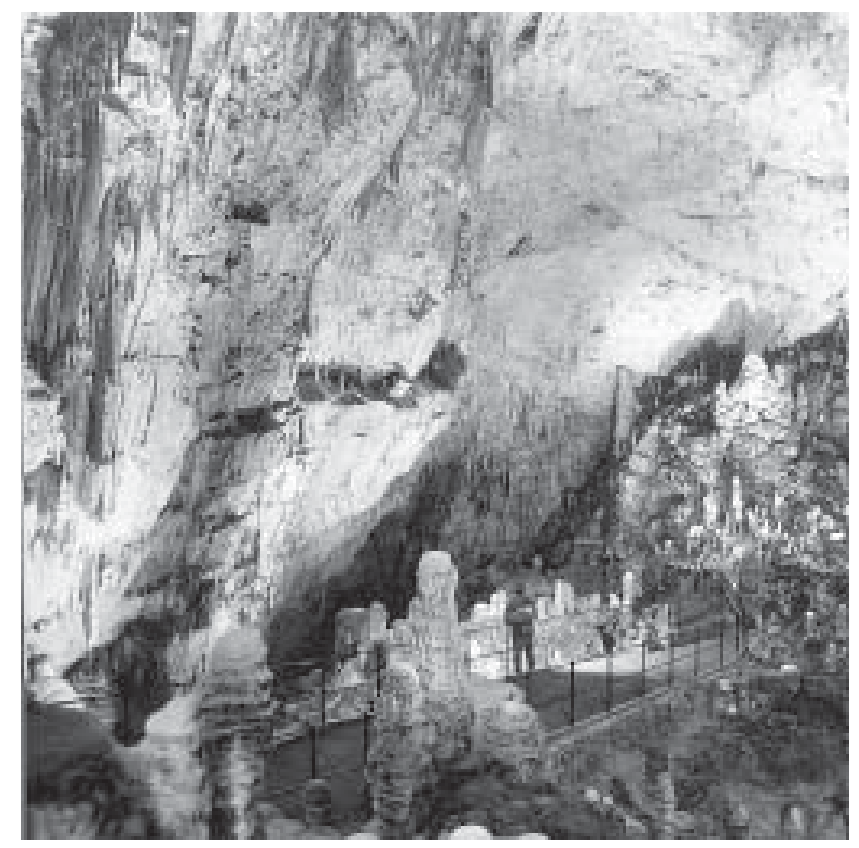

Fig. 5: The NE edge of Velika gora collapse chamber is formed along a reverse fault (ph. J. Hajna). Slika 5: SV rob podorne dvorane Velika gora se je oblikoval ob reverznem prelomu (foto J. Hajna). 


\section{CONCLUSIONS}

By detailed structural-lithological mapping of principal Slovene karst caves (Postojnska jama caves, Predjama and Škocjanske jame caves) it was determined that:

- $\quad$ interbedded slips

- thrusting deformations

- folding deformations and

- tectonically broken zones (fissured, broken and crushed zones)

are very favorable for initial and also for older and younger stages of passage development.

Even though in Slovenian karst areas the expressions such as interbedded slips and interbedded movements are mostly used, some authors working with structural geology use different terms. Fowler \& Winsor (1997) are describing interlayer slip that strongly influences the characteristics of fold growth. Bedding slip planes were identified as those showing: (1) bedding-parallel laminated veins or veins with consistently inclined fibres; and/or (2) striated (usually slick-ensided) bedding surfaces. Bedding slip planes and associated slip-striated laminated quartz veins developed during flexural-slip folding (Fowler \& Winsor 1997).

Frictional slip along bedding planes contributes to fault-related folding of layered rocks. Slip along bedding planes contributes to and is evidence of folding. This so-called flexural slip is manifest either as shear failure (e.g. distributed deformation in shales between stronger sandstone or carbonate units) or as frictional sliding on bedding interfaces between similar lithologies. Deformation mechanisms associated with flexural-slip folding may include frictional slip and/or joint development within flexed beds. Flexural-slip folding is a major component of the deformational process near faults within contractional and extensional tectonic regimes (Cooke \& Pollard 1997). Co-seismic slip along bedding planes observed within actively deforming folds (Yeats 1986) confirms the contribution of this mechanism to folding during earthquakes.

Nińo, Philip \& Chery (1998) use the expression bed-parallel slip and Koehn \& Passchier (2000) bedding-parallel slip.

For understanding the formation of karst features as grikes, karren, dolines, collapse dolines Čar (1982) and Čar \& Gospodarič (1984 and 1988) made an important step forward by division of tectonically fractured zones. Recently the structural bases for shaping of dolines was introduced by Čar (2001).

\section{REFERENCES}

Averbuch, O., Frizon de Lamotte, D. And Kissel, C., 1992: Magnetic fabric as a structural indicator of the deformation path within a fold-thrust structure: a test case from the Corbičres (NE Pyrenees, France).- Journal of Structural Geology, v. 14, 461-474.

Cooke M. L. \& Pollard, D. D., 1997: Bedding-plane slip in initial stages of fault-related folding.Journal of Structural Geology, Vol. 19, Nos 3-4, 567-581.

Čar, J., 1982: Geološka zgradba požiralnega obrobja Planinskega polja (Geological setting of the Planina polje ponor area).- Acta carsologica X (1981), 75-105, Ljubljana.

Čar, J. \& Gospodarič, R., 1984: O geologiji krasa med Postojno, Planino in Cerknico (About geology of karst among Postojna, Planina and Cerknica).- Acta carsologica XII (1983), 91-106, Ljubljana. 
Čar, J. \& Gospodarič, R., 1988: Geološka zgradba in nekatere hidrološke značilnosti bruhalnika Lijaka (Geological setting and some hydrological properties of Lijak effluent).- Acta carsologica XVII, 13-32, Ljubljana.

Čar, J. \& Šebela, S.,1998: Bedding planes, moved bedding planes, connective fissures and horizontal cave passages (Examples from Postojnska jama cave).- Acta carsologica XXVII/2, 75-95, Ljubljana.

Čar, J., 2001: Structural bases for shaping of dolines.- Acta carsologica 30/2, 239-256, Ljubljana. Davies W. E., 1960: Origin of caves in Folded Limestone.- NSS Bulletin, vol. 22, part 1, 5-18.

Farris Lapidus D., 1990: Collins dictionary of geology.-565 p., London and Glasgow.

Ford D. C. \& Ewers, R.O., 1978: The development of limestone cave system in the dimensions of length and depth.- Can. J.Earth Sci., 15, 1783-1798.

Fowler, T.J. \& Winsor, C.N., 1997: Characteristics and occurrence of bedding-parallel slip surface and laminated veins in chevron folds from the Bendigo-Castlemaine goldfields: implications for flexural-slip folding.- Journal of Structural geology, Vol. 19, No. 6, 799-815.

Frizon de Lamotte, D., Mercier, E., Dupré la Tour, A., Robion, P. \& Averbuch, O., 1997: Cinématique du plissement et déformation interne des roches. L'exemple du pli de Lagrasse.- C.R. Acad. Sci. Paris, t. 324, série II a, 592-598.

Gospodarič, R., 1964: Sledovi tektonskih premikov iz ledene dobe v Postojnski jami (Traces of the tectonic movements in the glacial period in the Postojna cave).- Naše jame 5 (1963), 5-11, Ljubljana.

Gospodarič, R., 1965: Tektonika ozemlja med Pivško kotlino in Planinskim poljem ter njen pomen za sistem Postojnskih jam.- 179 pp. Postojna, unpublished report.

Gospodarič, R., 1976: Razvoj jam med Pivško kotlino in Planinskim poljem v kvartarju (The Quaternary Caves Development Between the Pivka Bassin and Polje of Planina).- Acta carsologica 7, 8-135, Ljubljana.

http://www.u-cergy.fr/rech/labo/equipes/tecto/Equipe/Christine_page_web/tt99.htm

Knez, M., Kogovšek, J., Kranjc, A., Mihevc, A., Šebela, S. \& Zupan Hajna N., 1995. National report for Slovenia. In: COST action 65: hydrogeological aspects of groundwater protection in karstic areas: final report.- Luxembourg: European commission, 247-260, Brussels, Luxembourg.

Knez, M., 1998: The influence of bedding-planes on the development of karst caves (A study of Velika dolina at Škocjanske jame caves, Slovenia).- Carbonates and Evaporites, vol. 13, number 2, 121-131.

Koehn, D. \& Passchier, C. W., 2000: Shear sense indicators in striped bedding-veins.- Journal of Structural Geology, Vol. 22, No. 8, 1141-1151.

Laumonier, B., Marignac, C. And Gasquet, D., 1995: Cinématique d'un front de chevauchement: l'avant-pays de la nappe des Corbiere aux environs de Lagrasse (Aude, France).- C.R. Acad. Sci. Paris, t. 321, série II a, 1195-1201.

Nińo, F., Philip. H. \& Chery, J., 1998: The role of bed-parallel slip in the formation of blind thrust faults.- Journal of Structural geology, Vol. 20, No. 5, 503-516.

Placer, L., 1981: Geološka zgradba jugozahodne Slovenije (Geologic structure of southwestern Slovenia).- Geologija 24/1, 27-60, Ljubljana.

Placer. L., 1982: Tektonski razvoj idrijskega rudišča (Structural history of the Idrija mercury deposit).- Geologija 25/1, 7-94, Ljubljana. 
Renault, P., 1967: Le probleme de la Spéléogenčse. Annales de spéléologie, 22, 5-21, 209267.

Šebela, S. \& Čar, J., 1991: Geological setting of collapsed chambers in Vzhodni rov in Predjama cave.- Acta carsologica 20, 205-222, Ljubljana.

Šebela, S., 1995: Geološke osnove oblikovanja največje podorne dvorane v Postojnski jami-Velike gore.- Annales 7/95, 111-116, Koper.

Šebela, S., 1998: Tectonic structure of Postojnska jama cave system.- Založba ZRC 18, 112 pp., Ljubljana.

Waltham, A.C., 1971: Controlling factors in the development of caves. Transactions of the Cave Research Group of Great Britain, 13, 73-80.

www.schottishgeology.com/glossary.html

Yeats, R.S., 1986: Active faults related to folding.- In Studies in Geophysics, ed. Wallace R.E., 63-79, National Academic Press, Washington, DC.

\section{UPORABA STRUKTURNO GEOLOŠKIH IZRAZOV IN NJIHOV POMEN ZA KRAŠKE JAME}

\section{Povzetek}

Razumevanje geološke zgradbe je eden od ključnih elementov razumevanja razvoja in oblikovanja kraških terenov. Strukturno geološke raziskave na kraških terenih zajemajo enake strukturno geološke izraze kot na drugih geoloških terenih. Ker pa imamo na krasu opravka s posebnimi geomorfološkimi izrazi, se nekateri strukturno geološki elementi, ki so na poseben način povezani z določenimi kraškimi oblikami, uporabljajo kot posebni termini, ki so različni od terminov v uporabi na nekraških terenih. Na slovenskem krasu lahko ločimo dva najpomembnejša strukturna elementa, ki sta pomembna za razvoj jamskih rovov, in sicer:

- lezike (tektonsko deformirane)

- in tektonske strukture (prelomi, deformacije narivanja in gubanja, tektonsko pretrte cone (razpoklinske, porušene in zdrobljene)).

V Tabeli 1 so zbrani podatki o uporabi izrazov za tektonsko deformirane lezike. V Postojnski jami je medplastne zdrse prvi omenjal Gospodarič $(1965,1976)$. V 90-ih letih smo uporabljali izraze kot: zdrsne lezike, lezike poudarjene z medplastnimi zdrsi, medplastni zdrsi so deformirali plastnatost in lezike deformirane z medplastnimi zdrsi (Čar \& Šebela 1998, Šebela 1998). Dejstvo je, da so medplastni zdrsi povezani z razvojem Postojnske antiklinale (Gospodarič 1976, Šebela 1998).

Na primeru študije Velike doline v Škocjanskih jamah je Knez (1998) vpeljal izraz nosilna lezika.

V Tabeli 2 so predstavljeni izrazi, ki se uporabljajo za tektonsko pretrte cone v karbonatnih kamninah. V Stari jami v Postojnski jami (Slika 3) najdemo močno tektonizirane lezike. V primerjavi z duplexom »la Cagaličre« (Slika 4) (Averbuch et al., 1992; Laumonier et al., 1995; Frizon de Lamotte et al., 1997) lahko tudi v Stari jami govorimo o duplexu manjših dimenzij. Oblikovanje duplexa (Slika 2) je povezano z narivanjem in gubanjem. 
Podorna dvorana Velika gora v Postojnski jami (Slika 4 in 5) se je oblikovala ob dinarsko usmerjenem reverznem prelomu. Reaktiviranje prelomne cone in odnašanje podornega materijala je ustvarjalo pogoje za oblikovanje podorne dvorane (Šebela, 1995).

V letih 1982 (Čar) ter 1984 in 1988 (Čar \& Gospodarič) je bila vpeljana klasifikacija tektonsko pretrtih con na: razpoklinsko, porušeno in zdrobljeno cono. V letu 2001 je Čar svojo klasifikacijo uporabil tudi za razlago strukturnih osnov oblikovanja vrtač.

V najdaljših slovenskih jamah, kot so Postojnska, Predjama in Škocjanske jame so za razvoj rovov v inicialnih, kot tudi v starejših in mlajših obdobjih zelo ugodni medplastni zmiki, deformacije narivanja in gubanja ter tektonsko pretrte cone (razpoklinske, porušene in zdrobljene). 